\title{
Respiratory failure caused by cardiac dysfunction triggered by bronchiolitis
}

\author{
Suzu Imamura, Kenichi Tetsuhara 두, Shunsuke Fujii, Mamoru Muraoka
}

Department of Critical Care Medicine, Fukuoka Children's Hospital, Fukuoka, Japan

\section{Correspondence to} Dr Kenichi Tetsuhara; ken-tetsuhara@mti.biglobe.ne.jp

Accepted 1 July 2021
A 3-month-old female weighing $3.6 \mathrm{~kg}$, with trisomy 21 , who had undergone pulmonary artery banding for atrioventricular septal defect 2.5 months prior to the presentation was referred to our hospital because of nasal discharge and cough for 3 days and wheezing and decreased feeding for 1 day before admission. On arrival, her vital signs were respiratory rate, 60 breaths/min; oxygen saturation, 90\% (oxygen mask $5 \mathrm{~L} /$ minute); heart rate, 138 beats $/ \mathrm{min}$ and axillary temperature, $36.5^{\circ} \mathrm{C}$. Physical examination revealed subcostal retraction, prolonged expiration, diminished breath sounds, expiratory wheezing on bilateral lungs, grade III/VI pan-systolic murmur, hepatomegaly, livedo reticularis and cold extremities. According to multiplex PCR, she was positive for respiratory syncytial virus (RSV). On chest X-ray, extensive infiltrative shadows were observed in the left lung field. Although she has not been diagnosed as asthma, salbutamol inhalation was administered as diagnostic intervention for acute exacerbation of it; however, it did not improve respiratory distress. We suspected respiratory failure caused by bronchiolitis and compensated shock secondary to poor oral intake; thus, she was admitted to the intensive care unit.

Thereafter, point-of-care echocardiography revealed diffuse hypokinesis, and the left ventricular ejection fraction was $33.1 \%$ (video 1 ). The brain natriuretic peptide level was $9791 \mathrm{pg} / \mathrm{mL}$. Despite receiving endotracheal intubation and mechanical ventilation, oxygenation deteriorated; oxygen saturation was $70 \%$ with fraction of inspiratory oxygen of 1.0 and positive end-expiratory pressure of $14 \mathrm{cmH}_{2} \mathrm{O}$. We suspected acute exacerbation of heart failure and pulmonary hypertension. Therefore, dobutamine, diuretics and nitric oxide inhalation were initiated. Consequently, oxygenation

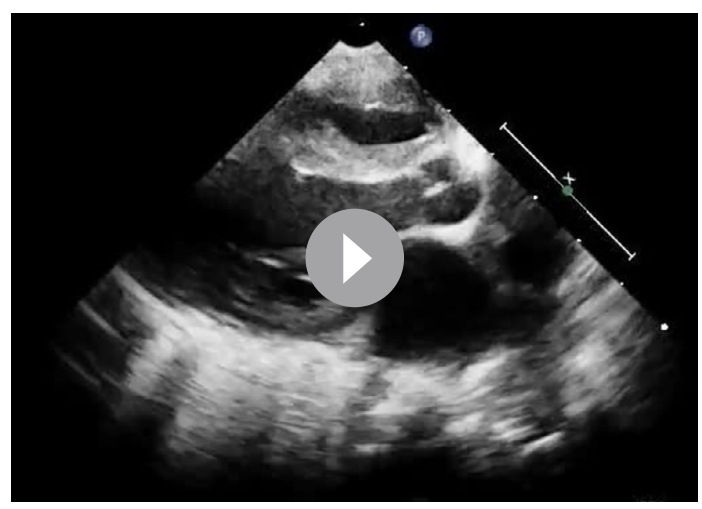

Video 1 Point-of-care echocardiography reveals a left ventricular ejection fraction of $33.1 \%$ on admission.

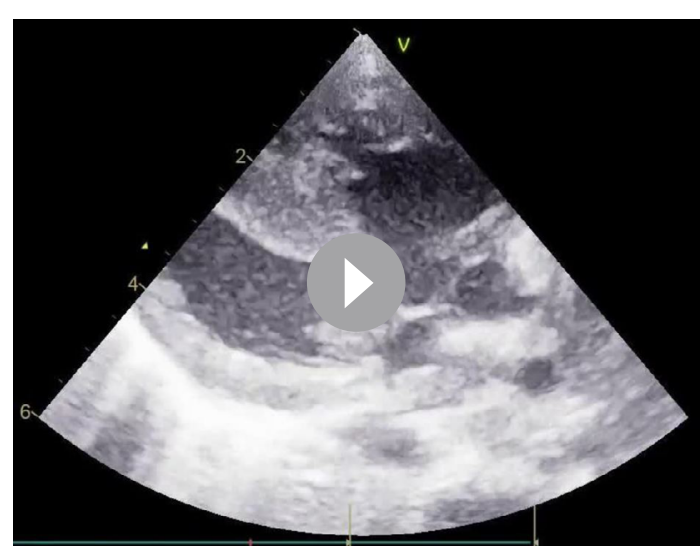

Video 2 Point-of-care echocardiography reveals a left ventricular ejection fraction of $69.1 \%$ on day 4 after admission.

gradually improved with oxygen saturation of $94 \%$ after nitric oxide inhalation, and the cardiac function also improved on the following day (video 2). She was extubated after 10 days and discharged 31 days after admission.

In this case, respiratory failure was caused by cardiac dysfunction triggered by RSV infection. RSV infection can lead to severe illness in infants with congenital heart disease. ${ }^{1}$ With infection, cardiac function may deteriorate in children with congenital heart disease. ${ }^{2}$ Therefore, point-of-care echocardiography should be performed in patients suffering from respiratory distress or respiratory tract infection with an identified pathogenic microorganism, especially if they have a history of heart disease.

\section{Patient's perspective}

The patient's mother said 'when she was admitted to the hospital, I only wanted her to survive.'

Learning points

- Point-of-care echocardiography should be performed in children with respiratory distress or respiratory tract infection with an identified pathogenic microorganism, especially if they have a history of cardiac disease.

- Respiratory syncytial virus infection can lead to severe illness in infants with congenital heart disease. 
We assumed that the left ventricular systolic dysfunction of this patient was induced by afterload elevation caused by agitation from dyspnoea, hypovolaemia secondary to poor oral intake, and infection. Considering the presence of cardiac dysfunction and infection, myocarditis is an important differential diagnosis in this case. Improvement of myocarditis takes weeks. ${ }^{3}$ However, in this case, cardiac function improved the next day after admission. Thus, myocarditis was less likely.

Acknowledgements We thank Dr. Yoshihiko Kodama and Dr. Keiichiro Mizuno for treatment of the patient and critical advice on the manuscript, and Dr. Noriyuki Kaku, Dr. Shoji Fukuoka, and Dr. Wakato Matsuoka for treatment of the patient.

Contributors SI wrote the manuscript under the supervision of KT, SF and MM.

Funding The authors have not declared a specific grant for this research from any funding agency in the public, commercial or not-for-profit sectors.
Competing interests None declared.

Patient consent for publication obtained.

Provenance and peer review Not commissioned; externally peer reviewed.

\section{ORCID iD}

Kenichi Tetsuhara http://orcid.org/0000-0001-6473-0326

\section{REFERENCES}

1 Welliver RC. Review of epidemiology and clinical risk factors for severe respiratory syncytial virus (RSV) infection. J Pediatr 2003;143:112-7.

2 Lee SH, Hon KL, Chiu WK, et al. Epidemiology of respiratory syncytial virus infection and its effect on children with heart disease in Hong Kong: a multicentre review. Hong Kong Med J 2019;25:363-71.

3 Caforio ALP, Pankuweit S, Arbustini E, et al. Current state of knowledge on aetiology, diagnosis, management, and therapy of myocarditis: a position statement of the European Society of cardiology Working group on myocardial and pericardial diseases. Eur Heart J 2013:34:2636-48.

Copyright 2021 BMJ Publishing Group. All rights reserved. For permission to reuse any of this content visit

https://www.bmj.com/company/products-services/rights-and-licensing/permissions/

BMJ Case Report Fellows may re-use this article for personal use and teaching without any further permission.

Become a Fellow of BMJ Case Reports today and you can:

- Submit as many cases as you like

- Enjoy fast sympathetic peer review and rapid publication of accepted articles

- Access all the published articles

Re-use any of the published material for personal use and teaching without further permission

Customer Service

If you have any further queries about your subscription, please contact our customer services team on +44 (0) 2071111105 or via email at support@bmj.com.

Visit casereports.bmj.com for more articles like this and to become a Fellow 